\title{
Etikken er sykepleiens grunnlag
}

Etikk er helt avgjørende som et grunnlag for å bli en kompetent og god utøver av sykepleie.

\section{Per Nortvedt}

Professor emeritus

Senter for medisinsk etikk, Universitetet i Oslo

Sykepleien 2016104 (8) (62 63)

DOI: 10.4220/Sykepleiens.2016.58516

Da sommeren begynte, tonet også debatten om sykepleierutdanningen ned. Diskusjonene om hva som er en god sykepleierutdanning, er imidlertid langt fra slutt. Samtidig som det reises kritikk av at man er for opptatt av omsorgstenkning og etikk, av kommunikasjon og de «myke fagene» i utdanningen, har det ved flere anledninger i sommer vært reist kritikk mot at medisinstudiet fokuserer for lite på humanistiske dannelsesfag som kommunikasjon og etikk (1). En norsk lege skrev i 2014 en doktoravhandling der hun ser betydning av sykepleiens omsorgsetikk også i medisinen (2). Det ser ut som man etterlyser mer av refleksjonsfag og humanistisk orientering i medisinutdanningen, samtidig som sykepleierutdanningen kritiseres for å være for dominert av disse fagområdene.

\section{Humanismen i medisin og helsefag}


Den norske filosofen Arne Johan Vetlesen skrev for 15 år siden en kronikk i Tidsskrift for Den norske legeforening der han etterlyste en større bevissthet $\mathrm{i}$ legeyrket og i legestudiet om legens sårbarhet i møte med pasientens sykdom og helsesvikt. Han ønsket også tilsvarende mindre oppmerksomhet rundt legens vellykkethet og allmektighet. Han sier: «Oppsummerende er min påstand at egen menneskelighet som sårbarhet, eller sårbarhet som tegn på medmenneskelighet, er legens fremste ressurs i møtet med pasienten. Den felles sårbarheten - 'det er du som har det slik, men det kunne ha vært meg' - gir selve tilgangen til pasientens ståsted». Han konkluderer: « $\AA$ være lege er å være profesjonsut øver og menneske i ett, men først og fremst menneske» (3, S. 1121).

Mens medisinen kan behandle sykdommer man tidligere ikke trodde var mulig, så sliter faget i dag med å anerkjenne kunnskap og refleksjon omkring sykdomsopplevelse, pasienterfaringer og etikk som viktige i faget, både klinisk og akademisk. Sykepleien, derimot, har alltid hatt sin styrke i å være opptatt av den personlige dimensjonen ved pasientperspektivet, av å forstå pasientens erfaring av sykdom og helsesvikt som grunnlag for å gi omsorg.

\section{Sykepleiefagets tre søyler}

Veldig enkelt kan man si at utøvelse av klinisk sykepleie står på tre ben.

Den må bygge på kunnskaper om behandling, helse og sykdom.

Man må ha ferdigheter i prosedyrer og terapeutiske teknikker for å kunne gjennomføre og/eller assistere behandling.

Man må ha de personlige egenskaper som er nødvendige for å realisere disse kunnskapene og ferdighetene.

Dette er selvsagt, alle er enige i det. Men så kommer noe som ikke er så selvsagt. Jeg vil hevde at det som er grunnlaget for våre kunnskaper, ferdigheter og ut $\varnothing v e l s e$, er etikk. Og hvordan forstår man da etikk? 


\section{Det etiske som sykepleiens kjerne}

Den fransk-litauiske filosofen Emmanuel Lévinas

hadde en stor tanke som han arbeidet med hele sitt liv, nemlig ideen om at etikk er første filosofi. Med det mente han at det er omtanken og ansvarligheten for andres sårbarhet som grunnlegger all kunnskap. Staten bygger sine tanker om institusjonell rettferdighet på tanker om upartiskhet og likeverd. Men vi bryr oss om rettferdighet, fordi vi bryr oss om hverandre. Barnet bæres inn i verden på mors hender og blikk (og far). $\AA$ samtale er å tale ut, utlevere seg i møte med en annen, som også utleverer seg til deg i tillit. Et slikt møte er grunntonen i tilværelsen.

Det samme gjelder for sykepleien som for medisinen og andre helsefag: at fagene er etiske i sin innerste kjerne. Etisk betyr ikke her at man alltid handler godt og rett, men det betyr at etikk er en forutsetning for muligheten til å handle godt og rett. Hva betyr så det? Jan Helge Solbakk skrev for 20 år siden at medisinen (jeg skriver her sykepleien) som sådan er normative på tre måter (4).

- Sykepleien normsetter grunnleggende menneskelige tilstander som sykdom og d $\varnothing$ d. Slike grunnvilkår ved å være menneske blir i sykepleien et utgangspunkt for å behandle, lindre og trøste.

- Sykepleien har et mandat om å handle og gjøre godt, til klientens/pasientens beste, velgjørenhet. Man er ikke til stede i sykerommet for å gjøre hva som helst, men å gjøre noe godt for et annet menneske, å hjelpe.

- Sykepleien er normativ i sitt vesen, ved at de fenomener som faget befatter seg med, er etisknormative i sitt vesen. De appellerer til utøverens handlingsgrunnlag. Pasientens smerte forplikter til lindring akkurat som et ubehagelig leie i sengen er en oppfordring om varsom tilrettelegging. 
Idéhistoriker Trond Berg Eriksen illustrerer dette siste poenget på en veldig god måte når han sier:

«Medfølelse på det mest elementære nivå er den forbindelsen mellom to kropper som fører til at en kjenner smerte når en annen utsettes for lidelser. Man tar seg uvilkårlig til benet når man ser bildet av en dramatisk amputasjon. Den som uforberedt blir vitne til et stikk i øyet eller st $\varnothing t$ i magen på en annen, rykker til og beskytter sine egne organer med bevegelsesreaksjoner. På et nivå som går forut for språket og begrunnelsene, finnes det åpenbart en sympati mellom kroppene. Kanskje dette er selve tilknytningspunktet mellom etikk, kunnskap og omsorg.» (5, s. 5)

Etikk forstått og formidlet på en god måte er helt avgjørende som et grunnlag for en god sykepleierutdanning og for å bli en kompetent og god utøver av sykepleie.

\section{Referanser:}

1. Valestrand E. NRK Ytring 1/8 2016 og Kaveh Rashidi, NRK Ytring 16/4 2016.

2. Martinsen EH. Toward a medical ethics that cares. A theoretical study of ill-being and care in medicine. Oslo: Faculty of medicine, University of Oslo, 2013. 3. Vetlesen AJ. Profesjonell og personlig? Legerollen mellom vellykkethet og sårbarhet. Tidsskr Nor legeforen 2001; 9 (121): 1118-1121. 4. Solbakk JH. Medisinen som møtested og markedsplass. Oslo: Forum Forlag, 1995. 5. Eriksen TB. Helse i hver dråpe, Oslo: Universitetsforlaget, 1995. 